\title{
PENGARUH PENERAPAN MEDIA AUDIOVISUAL TERHADAP PENGAJARAN LISTENING PADA MAHASISWA JURUSAN PENDIDIKAN BAHASA INGGRIS FKIP UMSU
}

\author{
Masyitah Noviyanti ${ }^{1}$, Imelda Darmayanti Manurung ${ }^{2}$ \\ ${ }^{1}$ Universitas Nahdlatul Ulama Sidoarjo \\ ${ }^{2}$ Universitas Muhammadiyah Sumatera Utara \\ e-mail: noviyuska@gmail.com
}

\begin{abstract}
Abstrak: Penelitian ini bertujuan untuk mengetahui hasil belajar mahasiswa jurusan bahasa Inggris dalam mata kuliah listening II yang diajarkan dengan menggunakan media audio visual. Metode penelitian yang digunakan ialah deskriptif kuantitatif, untuk menjabarkan dan mengukur sejauh mana pengaruh penggunaan media audio visual terhadap hasil pembelajaran mata kuliah listening pada mahasiswa semester II (dua), tahun akademik 2014/2015, Jurusan Pendidikan Bahasa Inggris, FKIP UMSU. Tujuan dari penelitian ini adalah untuk meneliti pengaruh penggunaan media audiovisual dan mengantisipasi kelemahan-kelemahan yang dimilikinya agar dapat menjadi alternatif teknik dalam pengajaran listening. Berdasarkan nilai t-uji, ditemukan $t_{\text {observe }}=9.39$. Itu berarti bahwa terdapat pengaruh pada penerapan media audiovisual terhadap pengajaran listening pada mahasiswa Jurusan Bahasa Inggris FKIP UMSU.
\end{abstract}

Kata kunci: audio visual, listening, media

\begin{abstract}
This study aimed to determine the students' learning results in Listening II subject which is taught by using audio visual media. Descriptive quantitave method is used to describe and measure the extent of the effect of the use of audio-visual media on the learning outcomes of the Listening II subject to the students of the second semester, Academic Year 2014/2015, majoring in English Education, FKIP, UMSU. The purpose of this study was to investigate the effect of the use of andiovisual media and anticipate its weaknesses in order to become an alternative technique in teaching listening. Based on the value of $t$-test, is found $t$-observe value $=9: 39, t$-table $=2.02$. if $t$ observe $>t$-table, then the alternative hypotheses $(\mathrm{Ha})$ is received (9.39> 2:02). That means that there is an influence on the using of the Audiovisual as Media in teaching listening to student's ability in English Education Department FKIP UMSU.
\end{abstract}

Keywords: audio visual, listening, media

\section{A. PENDAHULUAN}

Pengajaran bahasa Inggris pada tingkat perguruan tinggi tentunya memiliki pendekatan, strategi, metode dan media pembelajaran yang berbeda dengan tingkatan pembelajaran pada level yang lain. Setiap pengajar, dalam hal ini dosen, harus mampu mendesain metode, strategi dan media pengajaran yang tepat, guna memudahkan proses pencapaian diri dari tujuan pembelajaran, dan selanjutnya tujuan tersebut dapat berhasil tercapai. Hal ini tentunya bukanlah pekerjaan yang mudah dilakukan dalam arti setiap dosen harus mempunyai keterampilan dalam menyusun instruksional pengajarannya. Ketidakmampuan dosen dalam hal ini akan mengakibatkan kegagalan mahasiswa untuk mencapai tujuan pembelajarannya.

Pada tingkat perguruan tinggi, keterampilan menyimak (listening) mulai diajarkan pada semester I dalam mata kuliah listening I dan dilanjutkan dengan listening II, dan listening III 
pada semester berikutnya, khususnya di Fakultas Keguruan dam Ilmu Pendidikan, Universitas Muhammadiyah Sumatera Utara. Selain itu, setiap mahasiswa juga dibekali dengan ilmu bahasa lainnya seperti struktur bahasa (structure), pengucapan (pronunciation), membaca (reading), dan berbicara (speaking). Namun sepertinya bekal ini belum mampu mencukupi kebutuhan setiap mahasiswa dalam memahami keterampilan menyimak. Terbukti dengan masih rendahnya tingkat keberhasilan mahasiswa dalam pembelajaran listening tersebut.

Menurut pengamatan peneliti, kesulitan mahasiswa sangat beragam dalam memahami keterampilan listening. Berdasarkan hasil wawancara terhadap beberapa mahasiswa dan dosen Pengasuh mata kuliah Listening, dapat disimpulkan beberapa kesulitan yang dihadapi oleh mahasiswa dalam menguasai keterampilan menyimak (listening) sebagai berikut.

a. Wacana dalam listening diperdengarkan, tidak terdapat alat bantu bagi mahasiswa untuk menambah informasi terhadap apa yang mereka dengar, sehingga membutuhkan tingkat konsentrasi, dan perhatian yang sangat tinggi. Hal ini membuat mereka sangat rentan terhadap gangguan baik eksternal maupun internal.

b. Kesulitan dalam memahami makna (meaning) dalam sebuah percakapan atau wacana yang diucapkan atau dibacakan oleh native speaker. Artinya, mahasiswa tidak dapat memahami atau salah menafsirkan makna (semantics) yang terdapat dalam setiap kata atau frasa yang dipakai dalam percakapan atau wacana tersebut, tidak sesuai apa yang didengar dengan apa yang dipahami.

c. Kesulitan dalam mengantisipasi kecepatan berbicara (speech speed) pada materi yang didengar. Penyebab pada kesulitan ini pun beragam. Mulai dari kurangnya latihan menyi- mak, sampai dengan alasan tidak menggunakan alat bantu visual dalam belajar listening.

d. Kurangnya keterampilan mereka dalam membuat catatan (note - making). Pada umumnya mahasiswa tidak dapat memilah mana informasi yang penting dan kurang penting dari materi yang mereka simak, sehingga mereka berusaha untuk merekam semua informasi yang mereka dengar, dan hal ini mengakibatkan mereka kehilangan informasi yang lain, dan kesulitan dalam me-recall informasi yang dibutuhkan.

e. Rendahnya tingkat penguasaan kosa kata (vocabulary).Hal ini menyulitkan mereka ketika menyimak materi yang jarang atau tidak pernah mereka ketahui sebelumnya, misalnya bidang kesehatan, arsitektur, astronomi, biologi, dan lain-lain.

Hafni (2006: 2) mengatakan bahwa secara umum faktor-faktor yang memengaruhi prestasi belajar siswa digolongkan menjadi dua yaitu faktor yang berasal dari dalam diri siswa (internal) dan faktor yang berasal dan luar diri siswa (eksternal). Pada kenyataannya, tidak semua mahasiswa dapat mencapai hasil yang maksimal dalam belajar sesuai dengan apa yang diinginkan. Namun pada akhirnya setiap mahasiswa dapat dan bisa dibantu, baik secara individual maupun kelompok, untuk memperbaiki hasil belajar yang ingin dicapai, dalam hal ini pembelajaran listening, sesuai dengan kemampuan mereka. Untuk itu, bantuan sangat diperlukan dalam mengatasi kesulitan-kesulitan yang ditimbulkan dalam proses belajar-mengajar Listening. Bantuan yang diberikan dapat melalui berbagai pendekatan, metode dan alat bantu belajar yang digunakan disesuaikan dengan jenis dan sifat hambatan belajar yang dialami mahasiswa. Salah satu bantuan tersebut adalah melalui pengajaran dengan menggunakan metode audio visual yaitu metode 
yang menekankan hakikat sosial dan keterkaitan situational bahasa (Pateda: 144).

Dalam jurnal penelitian karya Sehat Simatupang dan Junita, Jurusan Fisika FMIPA Unimed, dengan judul Pengaruh Media Audio Visual terhadap Hasil Belajar Siswa pada Materi pokok Listrik Dinamis Kelas X Semester II SMAN 1 Binjai, jurnal penelitian tahun 2008, di uraikan hasil penelitian bahwa terdapat pengaruh positif antara media audiovisual terhadap hasil belajar siswa pada materi pokok listrik dinamis Kelas X SMAN 1 Binjai T.A 2007/2008. Jurnal di atas kemudian menjadi acuan bahwa penggunaan media audiovisual ini akan berpengaruh positif terhadap hasil belajar siswa.

Berdasarkan uraian-uraian di atas maka permasalahan yang diteliti dari penelitian ini adalah untuk mengetahui sejauh mana pengaruh penggunaan media audiovisual serta kelemahankelemahan audiovisual terhadap pengajaran listening pada mahasiswa jurusan bahasa Inggris FKIP UMSU.

\section{Rumusan Masalah}

Berdasarkan uraian pada pendahuluan maka permasalahan dari penelitian ini adalah:

1. Sejauh manakah pengaruh penggunaan media audiovisual terhadap hasil belajar mahasiswa dalam mata kuliah Listening?

2. Adakah kelemahan-kelemahan yang dimiliki media audiovisual terhadap pengajaran listening pada mahasiswa jurusan Pendidikan Bahasa Inggris FKIP UMSU?

3. Jika ada, bagaimanakah cara mengatasi kelemahan-kelemahan tersebut?

\section{Tujuan Penelitian}

Tujuan dari penelitian ini adalah sebagai berikut.
1. Untuk mengetahui sejauh mana pengaruh penggunaan media audiovisual terhadap hasil belajar mahasiswa dalam mata kuliah listening.

2. Menemukan dan mengatasi kelemahankelemahan yang dimiliki oleh media audiovisual sebagai salah satu media pembelajaran alternative dalam mata kuliah listening.

\section{B. TINJAUAN PUSTAKA}

\section{Teori Tentang Media Pembelajaran}

Kata "media" berasal dari bahasa Yunani medium yang berarti perantara atau pengantara. Pengertian dari kata media cukup beragam, namun dapat disimpulkan bahwa media adalah segala sesuatu yang dapat digunakan untuk menyampaikan informasi/pesan yang disampaikan oleh pengirim (komunikator) dan ada penerima (komunikan). Dalam dunia pendidikan, media pembelajaran adalah segala sesuatu yang digunakan untuk menyalurkan pesan serta dapat merangsang pikiran, perasaan, perhatian, dan kemampuan peserta didik sehingga dapat mendorong terjadinya proses belajar yang disengaja, bertujuan dan terkendali. Sejalan dengan pengertian yang disampaikan oleh Gagne (1985), yang menyatakan bahwa media merupakan berbagai jenis komponen dalam lingkungan siswa yang dapat merangsang untuk belajar. Maka dapat disimpulkan bahwa media pembelajaran merupakan alat bantu yang berfungsi untuk menjelaskan sebagian dan keseluruhan materi pembelajaran yang sulit dijelaskan secara verbal ataupun abstrak. Media pembelajaran berfungsi mempermudah siswa dalam memahami materi pembelajaran.

Keterkaitan antara efektivitas proses belajar mengajar (pembelajaran) yang dipengaruhi oleh faktor metode dan media pembelajaran yang 
digunakan terdapat dalam kegiatan belajar mengajar itu sendiri, di mana pemilihan metode tertentu akan berpengaruh terhadap jenis media yang akan digunakan. Itu berarti bahwa harus ada kesesuaian di antara keduanya dalam mewujudkan tujuan pembelajaran.

Media pembelajaran telah menjadi bagian integral dalam pembelajaran. Bahkan keberadaannya tidak bisa dipisahkan dalam proses pembelajaran di sekolah. Hal ini telah dikaji dan diteliti bahwa pembelajaran yang menggunakan media hasilnya lebih optimal. Walter Mc Kenzie (2005: 45) dalam bukunya "Multiple Intelligences and Instructional Technology" mengatakan, media memiliki peran penting dalam pembelajaran di kelas, yang memengaruhi kualitas dan keberhasilan pembelajaran. Dalam bagian ini dipaparkan berbagai fungsi media dalam pembelajaran. Pemanfaatan media dalam pembelajaran dapat membangkitkan keinginan dan minat baru, meningkatkan motivasi dan rangsangan kegiatan belajar, dan bahkan berpengaruh secara psikologis kepada siswa (Hamalik, 1986). Selanjutnya, diungkapkan bahwa penggunaan media pengajaran akan sangat membantu keefektifan proses pembelajaran dan penyampaian informasi (pesan dan isi pelajaran) pada saat itu. Kehadiran media dalam pembelajaran juga dikatakan dapat membantu peningkatan pemahaman siswa, penyajian data/informasi lebih menarik dan tepercaya, memudahkan penafsiran data, dan memadatkan informasi. Jadi dalam hal ini dikatakan bahwa fungsi media adalah sebagai alat bantu dalam kegiatan belajar mengajar.

Sadiman, dkk (1993) menyampaikan fungsi media (media pendidikan) secara umum, adalah sebagai berikut: (1) memperjelas penyajian pesan agar tidak terlalu bersifat visual; (2) mengatasi keterbatasan ruang, waktu, dan daya indra, misal objek yang terlalu besar untuk dibawa ke kelas dapat diganti dengan gambar, slide, chart., peristiwa yang terjadi di masa lalu bisa ditampilkan lagi lewat film, video, foto atau film bingkai; (3) meningkatkan kegairahan belajar, memungkinkan siswa belajar sendiri berdasarkan minat dan kemampuannya, dan mengatasi sikap pasif siswa; dan (4) memberikan rangsangan yang sama, dapat menyamakan pengalaman dan persepsi siswa terhadap isi pelajaran.

Berdasarkan beberapa uraian fungsi media pembelajaran yang dikemukakan di atas, maka dapat disimpulkan bahwa penggunaan media dalam kegiatan belajar mengajar memiliki pengaruh yang besar terhadap alat-alat indra. Penggunaan media akan sangat membantu terjadinya pemahaman yang lebih baik pada siswa. Pembelajar melalui proses mendengarkan saja akan berbeda tingkat pemahaman dan lamanya "ingatan" dapat bertahan, ingatan siswa akan bertahan lebih lama melalui proses belajar dengan melihat dan sekaligus mendengarkan. Media pembelajaran juga mampu membangkitkan dan membawa pembelajar ke dalam suasana menyenangkan dan gembira, di mana ada keterlibatan emosional dan mental di dalamnya. Hal ini tentunya akan berpengaruh terhadap semangat mereka belajar dan kondisi pembelajaran yang lebih hidup, kemudian bermuara kepada peningkatan hasil belajar.

Penjabaran di atas dapat disimpulkan bahwa media pembelajaran digunakan sebagai alat untuk peningkatan atau mempertinggi mutu proses kegiatan belajar mengajar. Oleh karena itu, harus diperhatikan prinsip-prinsip penggunaannya sebagai berikut.

1. Penggunaan media pengajaran hendaknya dipandang sebagai bagian yang penting dalam suatu sistem belajar mengajar dan bukan hanya sebagai alat bantu yang berfungsi seba- 
gai tambahan yang digunakan bila dianggap perlu dan hanya dimanfaatkan sewaktu-waktu jika dibutuhkan.

2. Media pengajaran hendaknya dipandang sebagai sumber belajar yang digunakan dalam usaha memecahkan masalah yang dihadapi dalam proses belajar mengajar.

3. Guru hendaknya benar-benar menguasai teknik-teknik dan suatu media pengajaran yang digunakan. Guru seharusnya memperhitungkan untung-ruginya pemanfaatan suatu media pembelajaran.

4. Penggunaan media pembelajaran harus diorganisasi secara sistematis bukan sembarang menggunakannya.

\section{Metode Audiovisual}

Pateda (1990: 144) mengatakan bahwa proses belajar yang mendasari metode ini ialah psikologi gestalt, yang mengasumsikan bahwa manusia melihat sesuatu bergerak dan keseluruhan ke elemen yang lebih kecil metode ini menerangkan hakikat sosial dan keterkaitan situasional bahasa. Itu sebabnya tayangan visual dimaksudkan untuk menstimulasikan konteks sosial tempat bahasa itu gunakan si terdidik didorong untuk menyerap secara global tuturan yang ia dengar dari perekam yang kemudian dihubungkan dengan apa yang ia dengar. Si terdidik menggunakan indra dengar dan penglihatan sekaligus. Dengan kata lain, si terdidik tidak menganalisis apa yang didengar dan apa yang dilihatnya itu. Itu sebabnya ciri utama metode ini ialah skenario yang disuguhkan secara visual merupakan alat utama untuk melibatkan si terdidik ke dalam tuturan dan konteks yang bermakna (Stem, 1983: 466).

Belajar bahasa diperlihatkan dengan beberapa tahap. Tahap pertama, metode audiovisual dapat diterapkan yang memungkinkan si terdidik menjadi biasa dengan bahas sehari-hari yang dipolakan dalam francais fundamental, tahap kedua, melibatkan kapasitas untuk berbicara lebih banyak dengan topik-topik umum dan untuk membaca fiksi yang tidak khusus dan surat kabar, dan tahap ketiga, melibatkan lebih banyak penggunaan wacana khusus dan surat kabar, dan tahap ketiga melibatkan lebih banyak penggunaan wacana khusus yang proporsional dan hal-hal yang menarik lainnya.

\section{Strategi Pengajaran Menyimak (Listening)}

Tarigan (1993: 191) mengatakan bahwa dalam strategi pengajaran menyimak (terlebihlebih dalam bidang kognitif) yang dapat digunakan adalah sebagai berikut.

1. Rehearsal atau pengulangan nama-nama butir atau objek yang telah disimak.

2. Organization atau pengelompokan dan pengklasifikasian kata-kata, terminologi, atau konsep-konsep sesuai dengan cirri-ciri semantik atau sintaksis yang telah disimak.

3. Inferencing atau penggunaan informasi dalam teks lisan untuk menduga makna-makna butirbutir linguistic baru, meramalkan hasil/akibat, atau melengkapi bagian-bagian yang hilang.

4. Summarizing atau menyintesiskan secara segera apa-apa yang telah disimak untuk meyakinkan bahan informasi telah dipahami dan dikuasai.

5. Deducation, atau penerapan kaidah-kaidah untuk memahami bahasa yang disimak.

6. Imagery atau penerapan imaji-imaji visual untuk memahami dan mengingat informasi verbal baru dan penyimakan.

7. Transfer atau penggunaan informasi linguistic yang telah diketahui untuk member kemudahan bagi tugas pembelajaran baru. 
8. Elaboration atau merangkaikan ide-ide yang terkandung dalam informasi baru atau memadukan ide-ide baru dengan informasi yang telah diketahui. (Tarigan, 1993: 192).

Untuk menyarankan makna-makna katakata baru, dia juga memperhatikan kesamaankesamaan dalam akar baru dengan kata yang belum diketahui B2. Dalam bidang kategori social/afektif, Azhar (1989: 76) mengatakan bahwa menyimak digunakan strategi-strategi:

1. Cooperation atau bekerjasama dengan temanteman untuk memecahkan suatu masalah, mengumpulkan informasi, mengecek catatan atau memperoleh umpan balik pada kegiatan pembelajaran menyimak pemahaman.

2. Questioning for clarification atau memperoleh dari pengajaran atau teman-teman sekelas, penjelasan, uraian, dan contoh-contoh tambahan.

3. Self-talk atau penggunaan control mental untuk meyakinkan dari bawah kegiatan pembelajaran akan berhasil atau mengurangi suatu tugas pembelajaran menyimak.

\section{METODE PENELITIAN}

\section{Lokasi Penelitian}

Penelitian ini telah dilaksanakan di Universitas Muhammadiyah Sumatera Utara, Jl. Kapten Muchtar Basri No. 03 Medan, pada semester II (dua) Tahun Akademik 2014/2015 Jurusan Pendidikan Bahasa Inggris, Fakultas Keguruan dan Ilmu Pendidikan.

\section{Populasi dan Sampel}

Populasi dalam penelitian ini adalah semua mahasiswa semester II Jurusan Pendidikan Bahasa Inggris, Fakultas Keguruan dan Ilmu
Pendidikan, tahun akademik 2014/2015, yang terdiri atas 9 (sembilan) kelas paralel. Dengan menggunakan purposive sampling method, maka akan dipilihlah 2 (dua) kelas parallel yang memiliki nilai rata-rata rendah dalam mata kuliah listening. Untuk itu informasi nilai dari dosen Pengasuh mata kuliah Listening sangat dibutuhkan.

Dalam penelitian ini, sampel dibedakan menjadi 2 (dua) kelompok sebagai berikut.

1. Kelompok mahasiswa dengan pemanfaatan media audiovisual.

2. Kelompok mahasiswa tanpa media audiovisual.

\section{Metode Penelitian}

Penelitian ini menggunakan metode penelitian deskriptif kuantitatif, yaitu penelitian yang dilakukan untuk mengetahui hasil pemahaman dari apa yang diperdengarkan kepada mahasiswa berdasarkan teknik pemanfaatan media audiovisual yang digunakan. Ada dua variabel dalam penelitian ini, yaitu variabel bebas (media audiovisual) dan variabel terikat (listening).

\section{Teknik Pengumpulan dan Analisis Data}

Untuk mengumpulkan data ada beberapa tahapan yang dilakukan guna mengetahui pengaruh penggunaan media audio visual terhadap hasil belajar listening, maka akan dilakukan tahapan-tahapan sebagai berikut.

1. Pemberian pre-test

Pre-test diberikan untuk mengetahui kemampuan siswa sebelum dilakukannya pembelajaran dengan menggunakan atau tanpa menggunakan media audio visual di kelas eksperimen dan kelas kontrol.

2. Menghitung skor pre-test Setelah pemberian pre-test, maka seluruh lembar kerja pre-test mahasiswa dikumpulkan 
dan dihitung untuk mengetahui skor masingmasing siswa. Soal yang diberikan berjumlah 25 soal dan skor maksimal adalah 4 untuk jawaban benar.

3. Perlakuan proses pembelajaran

Penerapan pembelajaran pada kelas eksperimen dengan menggunakan media audio visual dan penggunaan teknik konvensional tanpa media audio visual pada kelas kontrol.

\section{Pemberian post-test}

Post-test di berikan untuk mengetahui efek penerapan penggunaan media audio visual atau efek pengajaran tanpa media audio visual pada kelas kontrol dan kelas eksperimen.

5. Menghitung skor post-test

Lembar kerja hasil post-test siswa dikumpulkan dan dihitung untuk menemukan data hasil penelitian. Jumlah soal yang diberikan adalah 25 butir soal Listening dengan skor maksimal 4 untuk tiap jawaban benar.

\section{HASIL YANG DICAPAI}

\section{Hasil Penelitian}

Pengumpulan data dilakukan dengan memberikan tes sebanyak 25 butir soal yang didistribusikan pada kelas eksperimen dan kelas kontrol. Setiap kelas diuji dengan pre-test dan post-test. Berdasarkan skor hasil pengumpulan data dapat dilihat bahwa pada kelas eksperimen, nilai terendah pada pre-test adalah 15 dan tertinggi adalah 60 . Sedangkan hasil post-test menunjukkan nilai terendah adalah 55 dan tertinggi adalah 90.

Sedangkan pada kelas kontrol ditemukan data nilai terendah pre-test adalah 5 dan tertinggi adalah 50 sedangkan hasil post-test menunjukkan skor terendah adalah 15 dan tertinggi adalah 60 .

\section{Pembahasan}

Berdasarkan perhitungan data, ditemukan rata-rata nilai kelas eksperimen sebagai berikut:

$\overline{X_{1}}=\frac{2 x_{1}}{n_{1}}$

$\overline{X_{1}}=\frac{1215}{42}$

$\overline{X_{1}}=28.93$

Berdasarkan perhitungan data, rata-rata nilai pada kelas kontrol adalah:

$\overline{X_{2}}=\frac{2 X_{2}}{n_{2}}$

$\overline{X_{2}}=\frac{580}{42}$

$\overline{X_{2}}=13.81$

Pada perhitungan data rumusan t-test digunakan untuk menemukan nilai t-observe pada kedua kelas sampel sebagai dasar penilaian pada penelitian ini:

$\mathrm{t}=\sqrt{\left[\frac{\sum \pi_{1}^{2}+\sum X_{2}^{2}}{m_{1}+n_{2}-2}\right]\left[\frac{1}{m_{1}}+\frac{1}{m_{2}}\right]}$

$\mathrm{t}=\frac{28.93-13.81}{\sqrt{\left[\frac{3176.79+2140.48}{42+42-2}\right]\left[\frac{1}{42}+\frac{1}{42}\right]}}$

$\mathrm{t}=\frac{15,12}{\sqrt{\left[\frac{5117,27}{82}\right][0,02+0.02]}}$

$\mathrm{t}=\frac{15.12}{\sqrt{[64.84][0.04]}}$

$\mathrm{t}=\frac{15.12}{\sqrt{2.59}}$

$\mathrm{t}=\frac{15.12}{1.61}$

$\mathrm{t}=9.39$

Berdasarkan nilai t-uji di atas, ditemukan $\mathrm{t}_{\text {observe }}=9.39$, dengan $\mathrm{df}=\mathrm{n}-2$. Maka, $42-2=$ $40, \mathrm{t}_{\text {table }}=2.02$. Jika $\mathrm{t}_{\text {observe }}>\mathrm{t}_{\text {table }}$, maka hypothesis alternative $(\mathrm{Ha})$ diterima $(9,39>2.02)$. Itu berarti bahwa terdapat pengaruh pada penerapan media audiovisual terhadap pengajaran listening pada mahasiswa Jurusan Bahasa Inggris FKIP UMSU. 


\section{E. KESIMPULAN DAN SARAN}

\section{Kesimpulan}

Setelah menghitung dan menganalisis data, maka disimpulkan sebagai berikut.

1. Hasil perhitungan $t_{\text {observe }}$ adalah 9.39 dan $t_{\text {table }}$ adalah 2.02. Fakta ini menunjukkan bahwa nilai $\mathrm{t}_{\text {observe }}$ lebih tinggi dari nilai $\mathrm{t}_{\text {table }}$. Itu berarti bahwa hipotesis alternative ( $\mathrm{Ha})$ diterima. Dengan kata lain, terdapat pengaruh pada penerapan media audiovisual terhadap pengajaran listening pada mahasiswa Jurusan Bahasa Inggris FKIP UMSU.

2. Kelemahan pada penerapan media audiovisual adalah pada teknis sarana prasarana pendukung proses pembelajaran di mana masalah-masalah teknis operasional menyebabkan ketidak efisien waktu yang berimbas pada lambatnya proses pembelajaran.

\section{Saran}

Terkait dengan simpulan di atas, maka beberapa saran disampaikan sebagai berikut.

1. Media audiovisual diharapkan dapat menjadi alternative teknik pengajaran listening dan mata kuliah lainnya, dan memberikan pengaruh baik pada kemampuan mahasiswa dalam memahami materi yang di sampaikan, serta memberikan kontribusi positif terhadap teoriteori pembelajaran, dan tenaga pengajar khususnya di lingkungan FKIP UMSU dan akademisi lainnya.

2. Kelengkapan dan kelayakan sarana prasarana pendukung proses pembelajaran merupakan faktor penting yang harus dipenuhi oleh lembaga pendidikan demi tercapainya proses pembelajaran yang maksimal.

\section{F. DAFTAR RUJUKAN}

Ali, Muhammad. 1982. Penelitian Pendidikan Prosedur dan Strategi. Bandung: Angkasa. Ansari, Khairil. 2002. Wacana Bahasa Indonesia. Medan: UMSU.

Arikunto, Suharmi. 1993. Prosedur Penelitian Suatu Pendekatan. Jakarta: Bina Angkasa. Azhar Arsyad. 1989. Keterampilan Berbahasa. Jakarta: Rineka Cipta.

Gagne, R. 1985. The Conditions of Learning. New York: Holt, Rinehar \& Winston.

Hasan, Chalidjah. 1990. Psikologi Pendidikan. IAIN Press.

Huda, Niamul. 1995. Kamus Pelajar Populer. Pekalongan: Bahagia

Pateda, Mansoer. 1990. Linguistik terapan. Yogyakarta: Penerbit Nusa Indah.

Sadiman, Arif. 1993. Media Pendidikan. Jakarta: Raja Grafmdi Persada.

Siregar Hafni Nur. 2006. Pengaruh Pengajaran Remedial Terhadap Prestasi Belajar Siswa Pokok Bahasan Jurnal di Kelas I SMK Bm. Jambi Medan. Skripsi UMSU. Medan: Tidak Dipublikasikan.

Stern, H.H. 1983. Fundamentals Concept of Language Teaching. London Oxford.

Tarigan HG. Djago. 1987. Teknik Pengajaran

Keterampilan Berbahasa. Bandung: Angkasa

Taringan, Henry Guntur. 1993. Strategi Pengajaran dan Pembelajaran. Bandung: Angkasa.

http://ibrary.walisongo.ac.id/digilib/files/disk1/ 140/jtptiain-himatunnaf-6966-1-skripsi1.pdf, accessed on 29/5/2014, 7.42 PM. 